\title{
FUNGSI DAN TUJUAN PENDIDIKAN INDONESIA
}

\author{
Oleh : \\ I Wayan Cong Sujana \\ SD Negeri 4 Bugbug \\ congsujana@gmail.com
}

diterima 7 Februari 2019, direvisi 15 Februari 2019, diterbitkan 29 April 2019

\begin{abstract}
ABSTRAK
Latar belakang tulisan ini adalah untuk membahas tentang (1) fungsi dan tujuan pendidikan di Indonesia. (2) Penyelenggaraan Pendidikan Nasional (3) Fungsi Dan Tujuan Pendidikan Bagi Masyarakat . Kajian ini penting sebagai dasar arah pelaksanaan pendidikan di Indonesia. Dari berbagai perrspektif tentang fungsi dan tujuan pendidikan telah jelas terlihat bahwa pendidikan di indonesia berupaya untuk menciptakan bangsa yang cakap, beriman, bertaqwa kepada Tuhan serta memilki pengetahuan yang baik dan wawasan kebangsaan. Pendidikan di Indonesi sangat berperan penting dalam membangu masyarakat. Melalui pendidikan,masyarakat melakukan transformasi budaya, menciptakan tenaga kerja, menciptakan alat kontrol sosial dan lain sebagainya. Dengan demikian perkembangan masyarakat dapat berjalan secara berkelanjutan. Berdasarkan kelima fungsi dan tujuan pendidikan bagi masyrakat tentunya masyarakat akan sangat diuntungkan dalam hal birokrasi, sosial dan ketenagakerjaannya.
\end{abstract}

\section{Kata Kunci: Fungsi Pendidikan, Tujuan Pendidikan}

\section{PENDAHULUAN}

Pendidikan merupakan upaya untuk membantu jiwa anak-anak didik baik lahir maupun batin, dari sifat kodratinya menuju kearah peradaban manusiawi dan lebih baik. Sebagai contoh dapat dikemukakan ; anjuran atau arahan untuk anak duduk lebih baik, tidak berteriak-teriak agar tidak mengganggu orang lain, bersih badan, rapi pakaian, hormat pada orang yang lebih tua dan menyayangi yang muda, saling peduli dan lain sebagainya merupakan salah satu contoh proses pendidikan. Sehubungan dengan itu, Dewantara (1967) pernah mengungkapkan beberapa hal yang harius digunakan dalam pendidikan, yakni ngerti-ngrosongelakoni(menyadari, menginsyafi, dan melakukan). Hal tersebut serupa dengan ungkapan orang sunda di jawa barat, bahwa pendidikan harus merujuk pada adanya keselarasan antara tekad-ucap-lampah (niat, ucapan, dan pernbuatan).

Pendidikan merupakan proses yang berkelanjutan dan tak pernah berakhir (never ending proces), sehinngga dapat menghasilkan kualitas yang berkesinambungan, yang ditujukan pada perwujudan sosok manusia masa depan, dan berakar pada nilai-nilai budaya bangsa serta Pancasila. Pendidikan harus menumbuihkembangkan nilai-nilai filosofis dan budaya bangsa secara utuh dan menyuluruh. Sehingga perlu adanya kajian yang lebih mendalam terhadap pendidikan, maka dari itu 
pendidikan mulai dipandang secara filsafat yang merujuk pada kejelasan atas landasan pendidikan itu sendiri (Mulyasa. 2012:2).

Didalam

pelaksanaan

pendidikan tentu saja tidak hanya mengedepankan penanaman semata melainkan penanaman karakter bangsa yang dimaksud juga telah diatur didalam undang-undang negara Indonesia. Hal ini dilakukan guna memberikan arah terhadap pelaksaqnaan dan perkemabngan pendidikan di Indonesia untuk masa yang akan datang. Dengan demikian pendidikan di Indonesia dapat memberikan kontribusi yang jelas terhadap masyarakat dan negara Indonesia. Di dalam undang-undang No. 20 Tahun 2003 tenntang sisjtem pendidikan nasional, telah diatur terkait arah dan cara pelaksanaan pendidikan nasional yanng didalamnya memuat tentang tujuan dan fungsi pendidikan di Indonesia. Dengan tujuan dan fungsi poendidikan yang telah terurai di dalam undang-undang tersebut arah pendidikan dapat terlihat secara jelas bahwa pendidikan di Indonesi bertujuan untuk mempersiapkan generasi bangsa yang lebih baik.

Meski telah diatur didalam undang-undang No. 20 tahun 2003, fungsi dan tujuan pendidikan juga dapat dikembangkan sesuai dengan visi dan misi institusi penyelengenggara pendidikan, hal inilah yang dimaksud dengan pelaksanaan pendidikan berbasis otonomi daerah. Sehingga output dari institusi pendidikan tersebut dapat terserap dan memiliki daya guna yang sesuai dengan kebutuhan masyarakat yang ada di lingkungan institusi pendidikan tersebut. Dengan demikian fungsi dan tujuan pendidikan nasional dapat dirasakan secara langsung oleh masyarkat dan pemerintah.

\section{FUNGSI DAN TUJUAN \\ PENDIDIKAN \\ Fungsi Pendidikan Nasional}

Fungsi dan tujuan pendidikan di Indonesia telah diatur didalam undang-undang No. 20 tahun 2003 tentang sisutrem pendidikan nasional. Di dalam undang-undang tersebut memuat segala hal yang bersangkuta dengan pelaksanaan pendidikan nasional di Indonesia yang meliputi dari pengertian pendidikan, fungsi dan tujuan pendidikan, jenis-jenis pendidikan, jenjang pendidikan, standart penddidikan dan lain sebagainya. Dengan demikian arah pendidikan di Indonesia sudah ditentukan dengan sedemikian rupa.

Mengacu pada undang-undang No.20 tahun 2003 tentang sistem pendidikan nasional fungsi pendidikan yaitu Pasal 3 yang menyatakan bahwa'Pendidikan nasional berfungsi mengembangkan kemampuan dan membentuk watak serta peradapan bangsa yang bermatabat dalam rangka mencerdaskan kehidupan bangsa,bertujuan untuk berkembangnya potensi peserta didik agar menjadi manusia yang beriman dan bertakwa kepada Tuhan Yang Maha Esa,Berakhlak mulia,sehat,berilmu,cakap,kreatif,man diri,dan menjadi warga negara yang demokratis serta bertanggung jawab.

Fungsi pendidikan adalah menghilangkan segala sumber penderitaan rakyat dari kebodohan dan ketertinggalan serta fungsi pendidikan Indonesia menyatakan bahwa pendidikan nasional berfungsi mengembangkan kemampuan dan membentuk watak serta peradaban bangsa yang bermartabat dalam rangka 
mencerdaskan kehidupan bangsa. Dari fungsi yang diurakan tersebut menunjukan bahwa pendidikan nasional Indonesi lebih mengedepankan akan pembangunan sikap, karakater, dan transpormasi nilai-nilai filosopis negara Indonesia. Hal ini bertujuan untuk meningkatkan rasa nasionalisme serta mampu bersaing di kancah internasional.

\section{Tujuan Pendidikan Nasional}

Kemudian tujuan pendidikan nasional Indonesia sesuai dengan undang-undang No. 20 tahun 2003 yaitu, Pendidikan diupayakan dengan berawal dari manusia apa adanya (aktualisasi)

mempertimbangkan dengan (potensialitas), dan diarahkan menuju terwujudnya manusia yang seharusnya atau manusia yang dicita-citakan (idealitas). Tujuan pendidikan itu tiada lain adalah manusia yang beriman dan bertaqwa kapada Tuhan YME, berakhlak mulia, sehat, cerdas, berperasaan, berkemauan, dan mampu berkarya; mampu memenuhi berbagai kebutuhan secara wajar, mampu mngendalikan hawa nafsunya; berkepribadian, bermasyarakat dan berbudaya. Implikasinya, pendidikan harus berfungsi untuk mewujudkan (mengembangkan) berbagai potensi yang ada pada manusia dalam konteks dimensi keberagaman, moralitas, moralitas, individualitas/personalitas, sosialitas dan keberbudayaan secara menyeluruh dan terintegrasi. Dengan kata lain, pendidikan berfungsi untuk memanusiakan manusia.

Tujuan Pendidikan Nasional, sesuai dengan Tap MPRS No. XXVI/MPRS/1966 tentang Agama, pendidikan dan kebudayaan, maka dirumuskan bahwa tujuan pendidikan adalah untuk membentuk manusia
Pancasila sejati berdasarkan pembukaan UUD 1945. Selanjutnya dalam UU No. 2 tahun 1989 ditegaskan lagi bahwa pendidikan nasional bertujuan untuk mencerdaskan kehidupan bangsa dan mengembangkan manusia Indonesia seutuhnya, yaitu manusia yang beriman dan bertaqwa terhadap Tuhan YME dan berbudi pekerti luhur, memiliki pengetahuan dan keterampilan, kesehatan jasmani dan rohani, berkepribadian yang mantap dan mandiri serta rasa tanggung jawab kemasyarakatan dan kebangsaan.

Dengan demikian pendidikan Indonesia lebih cenderung mengutamakan pembangunan sikap sosial dan religius dalam pelaksanaan pendidikan di Indonesia. Hal tersebut sesuai dengan Pancasila sila kesatu yaitu Ketuhanan Yang Maha Esa, didakan sila tersebut menujukan bahwa Indonesia sangat mengedepakan sikap spiritual dan pengakuan terhadap keberadaan Tuhan Yang Maha Esa. Sehingga tidaklah diragukan bahwa negara Indonesia dapat dikatakan negara yang paling religius setelah negara Pakistan.

Sebagaimana diungkapkan oleh A. Tresna Sastrawijaya, tujuan pendidikan adalah segala sesuatu yang mencakup kesiapan jabatan, ketrampilan memecahkan masalah, penggunaan waktu senggang secara membangun, dan sebagainya karena harapan setiap siswa berbeda-beda. Sementara itu tujuan pendidikan berkaitang dengan segenap bidang studi dapat dinyatakan lebih spesifik. Misalnya, pada pelajaran bahasa berguna untuk mengembangkan kemampuan berkomunikasi dengan mahir secara lisan maupun tulisan. Tujuan pendidikan menyangkut secara luas yang akan membantu siswa untuk masuk dalam kehidupan 
bermasyarakat

1991:26).

(Sastrawijaya.

S.Nasution menyatakan bahwa setiap sekolah mendidika anak supaya mampu menjadi anggota masyarakat yang berguna. Namun pendidikan di sekolah lebih sering tidak relevan dengan kehidupan masyarakat. Kurikulum pada umumnya lebih cenderung berfokus pada bidang studi yang dapat berfikir logis dan sistematis dan hal tersebut tidak nyata hubungannya dengan kehidupan sehari-hari anak didik. Apa yang dipelajari anak didik hanya mengutamakan kepentingan sekolah semata, bukan secara totalitas membantu anak didik agar hidup lebih baik, efektif dalam masyarakat (Nasution. 1999:148).

Pendidikan juga diharapkan untuk memupuk iiman dan taqwa kepada Tuhan Yang Maha Esa, meningkatkan pembangunan dan kemajuan politik, ekonomi, sosial, budaya, dan pertahanan keamanan. Dalam hal ini pendidikan diharapkan mampu mengembangkan wawasan anak terhadap ideologi, politik, agama, ekonomi, sosial, budaya, dan pertahanan secara tepat dan benar, sehingga dapat membawa kemajuan individu, masyarakat dan negara guna menciptakan pembangunan nasional. Pemahaman terhadap aspek-aspek demikian tidak boleh menyimpang dari tujuan dan kerangka pembangunan nasional. Jika, pembangunan nasional bertujuan untuk menciptakan pembangunan manusia Indonesia yang berilmu pengetahuan berteknologi dan beriman bertaqwa, pendidikan nasional tentunya harus berupaya untuk menuju ke arah pembangunan tersebut (Idi. 2014:71).

Penyelenggaraan

Pendidikan
Mengingat negara Indonesia merupakan negara kesatuan yaitu kesatuan dari berbagai suku, ras, dan agama selain itu pelaksanaan pendidikan di indonesia yang mengedepankan transpormasi nilainilai filosopis serta pelaksanaan pendidikan yang tidak dapap terlepas dari peran keluarga, masyarakat dan pemerintah, maka pelaksanaan pendidikan di Indonesia juga diatur didalam Undang-Undang No. 20 tahun 2003 pada Pasal 4 mengatakan sebagai berikut:

1. Pendidikan selengarakan secara demokratis dan berkeadilan serta tidak diskriminatif dengan menjujung tinggi Hak Asasi Manusia,Nilai

Keagamaan,Nilai Kultur,dan Kejemukan Bangsa.

2. Pendidikan di selenggarakan sebagai satu kesatuan yang sistematik dengan sistemte terbuka dan multimakna

3. Pendidikan di selenggarakan sebagai suatu proses pembudayaan dan pemberdayaan peserta didik yang berlangsung sepanjan hayat.

4. Pendidikan diselenggarakan dengan memberi keteladanan,membangun

kemauan, dan mengembangakan kreatifitas peserta didik dalam proses pembelajaran

5. Pendidikan diselenggarakan dengan mengembangkan budaya membaca,menulis, dan berhitung bagi segenap warga masyarakat

6. Pendidikan diselenggarakan dengan memperdayakan semua komponen Masyarakat melalui peran serta dalam 
penyelenggaraan dan pengendalian mutu layanan pendidikan.

Berdasarkan pasal tersebut pendidikan di Indonesia tidak hanya menjadi tannggung jawab bagi institusi pelaksana pendidikan atau sekolah semata, melainkan masyarakat dan pemerintah juga memiliki andil dalam mensukseskan pendidikan nasional Indonesia. Dengan demikian pelaksanaan pendidikan di Indonesia akan memilki output yang seseuia dengan kebutuhan masyarakat dan juga negara.

Dalam konteks itu, Khususnya pada jenjang Pendidikan Dasar dan Menengah,sekolah seyogyanya di kembangkan sebagai pranata atau tatanan sosial- Pedagogis yang kondusif atau memberi suasana bagi tumbuh kembangnya berbagai kualitas pribadi peserta didik. Sekolah sebagai bagian intergral dari masyarakat perlu dikembangkan sebagai pusat pembudayaan dan pemberdayaan peserta didik sepanjang hayat,yang mampu memberi

keteladanan,membangun kemauan,dan mengembangkan kreatifitas peserta didik dalam proses pembelajaran demokratis.

Dalam rangka semua itu mata pelajaran PPKn harus berfungsi sebagai wahana kurikuler pengembangan karakater warga negara Indonesia yang demokratis dan bertanggung jawab. Peran PPKn dalam proses pembudayaan dan pemberdayaan peserta didik sepanjang hayat,melalui pemberian keteladanan,pembangunan

kemauan,dan pengembangan kreatifitas peserta didik dalam proses pembelajaran. Melalui PPKn sekolah perlu dikembangkan sebagai pust pengembangan wawasan,sikap,dan keterampilan hidup dan berkehidupan yang demokratis. Dari dua konsep dasar tersebut dapat dikemukakan bahwa paradigma pendidikan demokrasi melalui PPKn yang perlu dikembangkan dalam lingkungan sekolah adalah pendidikan demokrasi yang bersifat multidimensional atau bersifat jamak.

Dalam konteks kehidupan masyarakat,kita melihat betapa masih besar nya kesenjangan antara konsep dan muatan nilai yuang tercermin dal;am sumber-sumber normative konstitusional dengan fenomena sosial, cultural, politik, ideologis, dan regiositas. Kita menyaksikan kondisi paradoksi antara nilai dan fakta dalam kehidupan masyarakat berbangsa dan bernegara RI sampai dengan saat ini. Alisyabana(1976) mengatakan bahwa "value as integratingforces and personality,society and culture" nilai merupakan perekat-pemersatu dalam diri masyarakat dan kebudayaan.

Secara psikologis dan sosial yang dimaksudkan dengan cerdas itu bukanlah hanya cerdas rasional tetapi juga cerdas emosional ,cerdas sosial dan cerdas spiritual.(Sanusi 1998,winataputra 2001) dengan kata lain individu yang cerdas pikirannya,perasaannya,dan

prilakunya. Oleh karena itu proses pendidikan tidak boleh dilepaskan dari proses kebudayaan yang pada akhirnya akan mengantarkan manusia menjadi insan yang berbudaya dan berkeadaban. Secara umum yang dimaksud dengan pembudayaan adalah proses pengembangan nilai norma dan moral dalam diri individulisme proses perlibatan peserta didik dalam proses pendidikan yang merupakan bagian intergral dari proses kebudayan bangsa Indonesia. 


\section{Fungsi Dan Tujuan Pendidikan Bagi Masyarakat}

Pendidikan dan masyarakat tidak dapat dipisahlan satu sama lain. Perkembangan suatu masyarakat sagat ditentukan dari sektor pendidikan dalam mempersiapkan sumber daya manusianya(SDM) yang sesuai dengan perkembangan jaman, dan perkembangan sumber daya manusia bangsa indonesia tidak terlepas dari undang-undangnya(Idi. 2014: 60).

Dari konsepsi yang sanngat matang dan telah diuraikan pada undang-undang maupun ketetapam MPR RI tentunya pendidikan di Indonesia harus memilki kontribusi yang nyata dan jelas terhadap kehidupan bermasyarakat. Didalam penyelenggaraannya pendidikan di Indonesia memberikan kelonggaran dan ruang bagi Institusi penyelenggara pendidikan atau sekolah untuk mengatiur visi dan misi sekolah supaya sesuia dengan keadaan lingkungan yang ada di sekitar sekolah, sehingga dapat membrikan outcome terhadap masyrakat maupun sekolah tersebut.

Program

pendidikan

didasarkan pada tujuan umum pendidikan yang diturunkan dari tiga summber yang meliputi keluarga, masyarakat, dan pemerintah. Yang diturunkan dari masyarakat yang mencakup konsep luas seperti memanusiakan manusia, membentuk manusia, manusia yang berkepribadian, manusai yang bertanggung jawab dan sebagainya. Tujuan umum ini menyangkut pertimbangan filsafat dan etika yang diturunkan dari harapan masyarakat, seperti apa yang telah tercantum dalam falsafah bangsa.

Dari berbgai pendapat terkait dengan fungsi dan tujuan pendidika diatas tentunya tidak ada perbedaan substansi. Suatu hal yang pasti bahwa fungsi dan tujuan pendidika di masyrakat sangat krusial dalam melanjutkan fungsi dan tujuan pendidikan di dalam sekolah dan keluarga, di mana satu sama lain tidak dapat dipisahkan satu sama lain, tetapiu integral dalam membentuk suatu sistem pendidika yang memberdayakan anak didik dalam pegertian yang sesungguhnya. Dalam Idi (2001:32) menyebutkan ada beberapa pengertian dan pemhaman terkait dengan fungsi dan tujuan pendidikan akan dijelaskan sebagai berikut;

Pertama, fungsi dan tujuan pendidikan sebagai sosialisasi. Di dalam masyarakat pra industri, generasi baru berusaha mengikuti cara hidup generasi sebelumbnya tidak melalui lembaga-lembaga sekolah seperti pada jaman sekarang. Pada jaman dulu para generasi bangsa melakukan peniruan terhadap orangornag sebelumnya dengan ikut terjun langsung kedalam fenomena yang ingin diketahuinya. Mulai dari mengamatai hingga menuri segala seesuatu yang dilakukan oleh orang dewasa. Untuk itu para anak-anak belajar mengenali bahasa dan simbol yanng berlaku didalam lingkup oranng-orang dewasa serta menyesuaikan diri seperti hal orang dewasa.

Dengan demikian majunya masyarakat dapat ditandai dengan kemajuan budaya yang komplek dan memilki refrensi antara kelompok masyarakat satu dengan yang lain. Masyarakat tersebut telah mengalami perubahan sosial. Ketentuan yang diterapkan dalam rangka merubah kebudayaan menjadi lebih kompleks tersebut terus mengalami teransformasi kepada generasi ke generasi berikutnya hingga bertemu 
dengan permasalahan yang baru. Maka dari itu perkembangan yang pesat tersebut tentunya membutuhkan tempat guna melakukan transformasi budaya yang lebih efisien dengan menggunakan sekolah-sekolah.

Preses mentransformasi, menjaga, dan mengembangkan budaya, nilai, tradisi, norma dan lain sebagainya, secarta langsung telah dibebankan pada dunia pendidikan karena pendidikan dipandang lebih mampu dalam mengemban tuigas tersebut. Selain itu keluarga, pemerintah, lembaga keagamaan, dan perekonomian juga ditekankan untuk melakukan tugas yang sama sehingga di setiap lini masyarakat tirikat ketat untuk melakukan tugas tersebut. Dalam permulaan pendidikanya sangatlah penting bagi anak didik dalam menelaah nilai-nilai tersebut. Hal ini dilakukan karena pada tahap awal seorang individu dapat memilki kritikal dan evaluasi yang rasional.

Pendidikan-pendidikan juga mempromosikan terkait cita-cita sosial yang akan dicapainya. Ssemua peserta didik didorong dan diarahkan untuk mengikuti kegiatan-kegiatan yang telah dilakukan oleh generasi sebelumnya karena semuanya dianggap sebagai budaya yang sedang berlaku. Dengan cara tersebut anakanak diarahkan untuk berperilaku yang sopan, hormat, dan juga patuh kepada orang tuannya dan norma-norma yang berlaku (Idi. 2014:73).

Kedua, Fungsi dan tujuan pendidikan sebagai kontrol sosial. Sekolah dalam menanamkan nilai-nilai dan loyalitas terhadap tatanan masyrakat harus berfungsi sebagai layanan sekolah untuk menjadi mekanisme kontrol. Durkheim menjelaskan bahwa pendidikan morang dipergunakan untuk meredam keedoisan dan kerakusan individual menjadi manusia yang beribtegral serta memilki tranggung jawab dan kesadaran sosial, dalam Jeane $\mathrm{H}$. Ballantine (1983:8). Melalui pendidikan yang demikian, setiap individu akan berupaya menerapkan nilai-nialai yang di dapatkanya keedalam kehidupan sehari-harinya. Selanjutnya sebagai anggota masyrakat individu memberikan dukungang dan berusaha untuk mempertahankan tatanan sosial yang berlaku.

Sekolah sebagai lembaga berfungsi untuk menjaga dan mengembangkan tatanan sosial dan kontrol sosial mempergunakan asimilasi dan niali-niali sub-grup beraneka ragam, kedalam nialai-nilai yang dominan dianut oleh masyarakat. Sekolah juga berfungsi sebagai pemersatu nilai sehingga dapat diterima di berbagai kalangan masyrakat. Di Indonesia, sekolah harus menanamkan filosofis Pancasila yang dianut oleh bangsa kpada para anak-anak didik.

\section{Ketiga, fungsi dan tujuan} pendidika sebagai pelestari budaya.disamping sekolah memilki perang pendting dalam mempersatukan budaya bangsa, sekolah juga menjadi alat pelestari budaya yang masih layak untuk dipertahankan. Seperti bahasa daerah, seni, budi pekerti dan segala upaya memberdayaka sumberdaya lokal guna kepentingan sekolah dan masyarakat. Fungsi sekolah sebagai konservasi nilai-nilai budaya daerah, yang meliputi 1) sekolah dijadikan sebagai salah satu lembaga masyrakat dalam rangka mempertahankannilai-nilai tradisonal masyrakat dari suatu massyarakat pada sutau masyarakat tertentu. 2) sekolah memilk,i tugas untuk mempertahankan nialai-niali budaya bangsa mempersatukan nilai- 
nilai yang beragam demi kepentingan nasional.

Untuk memenuhi dua tunttutan tersebut perlu disusun kurikulum yang baku dan berlaku disemua daerah serta memillki kesesuaian terhadap nilainilai dan kondisi daerah tersebut. Dalam hal ini sekolah bertanggung jawab untuk mendidik siswa untuk menjadi generasi yang cinta daerah, bangsa, dan tanah air.

Keempat, fungsi dan tujuan pendidikan sebagai seleksi. Dalam rangka memenuhi kebutuhan masyarakat dalam hal ketenaga kerjaan guna menempati jabatan dan fungsional tertentu harus melalui tiga tahap, yaitu seleksi, pelatihan, dan pengemabangan. Dalam hal seleksi sekolah melakukan penyaringan terhadap calon siswa yang hendak masuk kedalam sekolah tersebut dengan menggunakan NEM. Hal tersebutlah yang menjadikan terjadinya kesenjangan pendidikan di Indonesia, di mana calon siswa yang memilki NEM yang kecil dan dengan ekonomi yang kurang mencukupi tidak bisa mendapatkan sekolah yang bermutu. Dan hal tersebut juga berlaku dalam hal penempatan jabatan atau fungsional, mereka harus melalui berbagai seleksi guna menedapatkan tenaga kerja yang cakap dan terampil serta sesuia dengan jabatan yang sedang dipangkunya.

Sekolah sebagai lembaga pelatihan dan pengemabangan mempunyai dua hal yang meliputi 1) sekolah digunaakan untuk menyiapkan tenaga kerja yang profesional dalam bidang spesialis tertentu. Guna menampungnya sekolah membuka berbagai jurusan dan cabang ilmu guna menyiapkan tenaga ahli dibidanya. 2) sekolah digunakan sebagai alat untuk memotifasi para pekerja agare memilki tanggung jawab terhadap karir dan jabatan yang dipangkunya.

Sekolah mempunyai fungsi

pengajaran, pelatiham, dan pendidikan. Fungsi pengajaran yaitu menyiapkan tenaga kerja yang ahli dibidangnya. Fungsi latihan yaitu untuk menciptakan tenaga kerja yang terampil di bidangnya, sedangkan fungsi pendidikan yaitu mempersiapkan pribadi yang baik dan seorang pekerja yang sesuai dengan bidangnya. Jadi fungsi dan tujuan pendidikan inni merupakan perkembangan sosial seorang individu.

Kelima, fungsi dan tujuan pendidikan sebagai peruabahan sosial. Pendidikan memilki fungsi dan tujuan untuk melakukan perubahan sosial, yang meliputi : 1) melakukan reproduksi budaya. Didalam pendidikan siswa akan diajarakan denbgan kebiasaan-kebiaasaan baru yang nantinya akan merubah kebiasaan lama menjadi yang lebih modern, kebiasaan tersebut meliputi orientasi ekonomi, kemandirian, mekanisme, kompetensi, sikap kerja dan lain sebagainya. Usaha-usaha tersebut berdasarkan dengan pola pikir ilmiah yang secara nyata iitu meruapakan lawan bagi pola pikir yang lama, sehingga seseorang akan dapat dengan mudah melakukan pandangan yang objektif dan mempermudah manusia menguasai alam sekitarnya.

2) lembaga pendidikan sebagai defusi budaya. Kebijaksanaankebijaksaan sosial yang kemudian diambil tertentu berdasarkan dari hasil budaya dan defusi budaya. Sekolahsekolah tertentu baru, dan juga menanamkan nilai-nilai baru guna mempermudah siswa dalam menjadi anggota masyarakat.

Keenam, fungsi dan tujuan pendidikan sebagai partner 
masyarakat. Sekolah sebagai partner masyarakat hal ini disebabkan adanya timbal balik antara sekolah dengan masyarakat yang saling berkaitan. Antara kedua pihak tersebut memiliki manfaat dan arti yang sangat penting bagi pembinaan dukungan moral, material, dan pemanfaatan masyarakat sebagai sumber belajar. Hubungan antara ssekolah dengan masyarakat merupakan salah satu bentuk dalam membangun dan mengembangakan pertumbuhan pribadi seorang anak didik. Sekolah dalam hal ini adalah gambaran dari sistem sosial yang merupakan bagian integral dari suatu bentuk masyarakat, hal tersebut terurai dengan jelas dalam teori fungsional strukturalnya Tallcot Parson (Mulyasa. 2008:116).

\section{Fungsi Dan Tujuan Pendidikan Bagi Pemerintah}

Pendidikan merupakan salah satu sara yang digunakan oleh pemerintah guna melakukan penyelarasan dan proses pembentukan bangsa yang berguna bagi negara. Dalam hal ini pendidikan digunakan sebagai motor unttuk berbagai kepentingan mulai dari kepentingan politik hingga kepentingan sosial. Tidak jarang pendidikan dijadikan wacana utama atau jargon bagi para calon-calon pejabat guna meraih suara dari masyrakat, hal tersebut mulai dari program pendidikan gratis hingga pendidikan terbuka. Kesemuanya itu hanya menjadi wacana semata melihat keadaan yang sebenarnnya wacana tersebut sulit untuk dipenuhi. Dalam hal fungsi dan tujuan pendidikan bagi pemerintag pada dasarnya bertujuan untuk mempersiapkan generasi bangsa guna menjadi generasi yang lebih baik, semuanya terurai dalam penjelasan sebagai berikut :
Pertama,

Menciptakan

Generasi Penerus Bangsa.Manfaat pendidikan yang kedua adalah mamp untuk menciptakan generasi penerus bangsa yang expert atau ahli dalam berbagai bidang. Hal ini berhubungan dengan tersedianya berbagai macam jenjang pendidikan dan juga penjurusan yang ada, sehingga dapat membantu melahirkan banyak sekali generasi muda yang berguna bagi banyak orang sesuai dengan disiplin ilmu yang dipelajari

Kedua, Pendidikan sebagai alat untuk mengukur kepedulian terhadap generasi bangsa. Hal ini tertuang dalam undang-undang No.20 tahun 2003 pasal 4 ayat 6 yang manyatakan bahwa masyarakat memilki tanggung jawab akan pelaksanaan pendidikan di Indonesia. Dengan adanya kontribusi masayarakat terhadap pelaksanaan pendidikan nasional Indonesia diharapkan mayarakat menjadi sadar bahwa pentingnya memelihara dan mengembangkan bakat-bakat generasi mereka guna mengantarkan ke peradaban masyarakat yang lebih baik.

Selain itu dengan adanya perhatian dari masyarakat pelaksanaan pendidikan juga menjadi lancar sekolah-sekolah mendapatkan murid dan masyarakat mendapatkan kaum intelektual. Sehingga telah terjadi kesinambungan yang saling menguntungkan antara masyrakat dan pendidikan. Antara pendidikan dan sekolah, keluarga dan masyarakat terdapat saling keterkaitan. Di satu sisi, pendidikan adalah bagian dari kehidupan yang dituntut untuk mampu mengikuti perkembangan di dalamnya. Di pihak lain, karena misi yang diemban oleh pendidikan tidak larut di dalam pengarh lingkungan sekitarnya. Pendidikan, dalam hal ini, tidak hanya akan menjadi buih dalam gelombang 
ADI WIDYA: Jurnal Pendidikan Dasar

Volume. 4, Nomor 1 April 2019

ISSN: 977252754401

http://ejournal.ihdn.ac.id/index.php/AW

perkembangan zaman. Berdasarkan nilai-niilai yang diiedealkan, pendidikan akan selalu berupaya menjalani kehidupan (Idi. 2014:59).

$$
\text { Ketiga, Sebagai alat }
$$

transformasi nilai. Pendidikan di negara Indonesia tidak hanya mengesah kemampuan koqnitif siswa atau peserta didik semata melainkan pendidikan di Indonesia yang didasarkan pada pasal 4 undangundang No.20 tahun 2003 lebih menekankan kesesuaian antara pendidikan dengan nilai, norma, budaya masayarakat setempat. Hal tersebut bertujuan untuk menghindari ketimpangan anntara output pendidikan dengan kebutuhan masyarakat. Sehingga didalam pelaksanaan pendidikan Indonesia lebih mengutamakan transformasi nilai- nilai, norma, budaya yang ada di lingkungan sekolah tersebut berada.

\section{Dengan} menggunakan pendidikan sebagai alat transformasi nilai ini sangata menguntungkan bagi masyrakat, yang mana nilai-nilai dan norma serta budaya masyarakat setempat dapat diwariskan kepada generasi selanjutnya. Sehingga terjadi kebertahanan terhadap nilai-nilai masyarakat tersebut (Idi. 2014:61).

\section{Keempat,}

Memberikan

Informasi dan Pemahaman. Manfaat pendidikan pertama adalah untuk meningkatkan serta memberikan informasi serta pemahaman terhadap ilmu pengetahuan secara menyeluruh kepada setiap anggota didik. Hal ini merupakan salah satu hal yang paling penting dan merupakan tujuan serta manfaat utama dari pendidikan. Dengan adanya pendidikan, maka setiap peserta didik akan dibantu dalam memahami dan mengenal berbagai macam ilmu pengetahuan yang terus berkembang.

Kelima, Mencegah Terjadinya Tindak Kejahatan. Dengan adanya pendidikan, maka seseorang akan memahami apa yang baik dan juga apa yang salah. Hal ini tentu saja akan berpengaruh dan juga bermanfaat untuk mencegah terjadinya tindak kejahatan.

Keenam, Membentuk Karakter Bangsa. Manfaat pendidikan selanjutnya adalah untuk membentuk karakter bangsa yang bermartabat dan juga bermoral. Sejalan dengan tujuannya, pendidikan juga harus bermanfaat untuk meningkatkan dan juga membentuk karakter dari bangsa yang bermartabat dan juga bermoral baik. Hal ini tentu saja akan sangat berpengaruh terhadap kemajuan dari Negara kita.

\section{SIMPULAN}

Dari berbagai perrspektif tentang fungsi dan tujuan pendidikan telah jelas terlihat bahwa pendidikan di indonesia berupaya untuk menciptakan bangsa yang cakap, beriman, bertaqwa kepada Tuhan serta memilki pengetahuan yang baik dan wawasan kebangsaan yang luas seperti yang tertuang dalam sila pertama.

Pendidikan di Indonesi sangat berperan penting dalam membangu masyarakat.

Melalui pendidikan,masyarakat melakukan transformasi budaya, menciptakan tenaga kerja, menciptakan alat kontrol sosial dan lain sebagainya. Dengan demikian perkembangan masyarakat dapat berjalan secara berkelanjutan. Berdasarkan kelima fungsi dan tujuan pendidikan bagi masyrakat tentunya masyarakat akan sangat diuntungkan dalam hal birokrasi, sosial dan ketenagakerjaannya.

Selain

pemerintahpun masyarakat, merasakan 
ADI WIDYA: Jurnal Pendidikan Dasar

Volume. 4, Nomor 1 April 2019

ISSN: 977252754401

http://ejournal.ihdn.ac.id/index.php/AW

dampak positif dari adanya kegiatan pendidikan. Di mana pendidikan dijadikan wadah atau tempat untuk menciptakan generasi yang ahli dan terampil dalam bidang masing-masing. Melalui pendidikan tersebut pemerintah akan lebih meudah dalam hal mananggulangi kejahatan sosial, pengangguran, kemiskinan dan lain sebagainya. Hal tersebut disebkan, karena pendidika tidak hanya berpaku pada trasformasi sikap dan budaya semata, melainkan pendidikan juga menciptakan tenaga-tenaga ahli dibidang ekonomi.

\section{DAFTAR PUSTAKA}

Idi, Abdullah. 2001. The Conditions For Learning at University: A Comparasion Between Indonesia and Tasmania, Australia. Palembang: Unsri Pers.

Idi, Abdullah. 2014. Sosiologi Pendidikan. Jakarta: Rajawali Pers.

Lickona, Thomas. 2013. Pendidikan Karakter. Bandung: Nusa Media.

Mulyasa. 2008. Menjadi Guru Profesional: Menciptakan Pembelajaran Kreatif Dan Menyenangkan. Bandung: Remaja Rosdakarya.

Mulyasa. 2012. Manajemen Pendidikan Karakter. Jakarta: Bumi Aksara.

Mulyasa. 2012. Manajemen pendidikan karakter. Jakarta: Bumi aksara

S. Nasution. 2009. Sosiologi Pendidikan. Jakarta: Bumi Aksara Pers.

Sastrawijaya, A.Tresna. 1991. Pengembangan Program Pembelajaran. Jakarta: Rineka Cipta. 